\title{
Analysis of Science and Technology Pre-service Teachers' Beliefs on the Construction of the Teachers' Professional Identity during the Initial Training Process
}

\author{
Elisa Pérez Gracia ${ }^{1,2}$, Rocío Serrano Rodríguez ${ }^{1 *}$, Alfonso Pontes Pedrajas ${ }^{1}$ \\ ${ }^{1}$ Universidad de Córdoba, SPAIN \\ ${ }^{2}$ Loyola Andalucía University, SPAIN
}

Received 12 December 2018 - Revised 22 March 2019 • Accepted 22 March 2019

\begin{abstract}
This study focuses on exploring the beliefs regarding the construction and development of Teacher's Professional Identity (TPI) of Secondary Education Master's Degree (SEMD) students from the areas of Science and Technology. An 'S-TPI' questionnaire, measured using a Likert scale, was used to obtain the opinions of 279 future teachers in the 2014-2018 academic years. After analysing the data, no significant differences were found between the two groups (Science and Technology). However, there were significant differences in the responses obtained for the four dimensions on the scale with regard to the students' gender. We noticed an important relationship between the global view of professional identity and the development of educational skills linked to socio-educative and methodological aspects. These results may contribute to improving knowledge concerning future teachers' beliefs and have served as a basis on which to design activities that will enable us to integrate TPI into the initial training process.
\end{abstract}

Keywords: secondary education, science and technology, students' beliefs, teacher's professional identity

\section{INTRODUCTION}

Several studies have stated that aspiring Secondary Education teachers begin their initial teacher training studies with different views and conceptions of the teaching professionalism and they show different attitudes regarding the process to be followed in order to achieve adequate pedagogical training to face the challenges and address the demands for improvement in this educational stage (Buldur, 2017; Esteve, 2009; Hong, 2010; Smith \& Darfler, 2012). For this reason, we have been working on a research project for a long time related to the following problem: What Science and Technology Secondary Education pre-service teachers think about the teaching profession and to what extent the initial training process contribute to improve these thoughts while promoting the development of teachers' professional identity (TPI)? Moreover, this project consists of three different stages (Figure 1).

Within the general framework of the aforementioned project, this study belongs to the second stage, in which it is intended to analyse the beliefs of future Science and Technology teachers on the TPI and its evolution during the Master's Degree in Secondary Education Teacher Training. For this purpose, a scale of beliefs on various aspects related to the development of the TPI (Serrano Rodríguez, Pérez Gracia \& Pontes Pedrajas, 2018) has been designed based on the ideas gathered in the reflection and debate activities in the classroom during the previous phase.

After proceeding with the validation of the new scale (Serrano Rodríguez, Pérez Gracia \& Pontes Pedrajas, 2018), several complementary studies have been designed to understand the main characteristics of pre-service teachers' beliefs about TPI and the aspects that may influence its evolution. In the context of the second phase of the research project, it should be noted that the specific problem addressed is directly related to the following question: What are the main characteristics presented by the beliefs of future Science and Technology teachers

(C) 2019 by the authors; licensee Modestum Ltd., UK. This article is an open access article distributed under the terms and conditions of the Creative Commons Attribution License (http://creativecommons.org/licenses/by/4.0/). \eperez@uloyola.es $\square$ rocio.serrano@uco.es (*Correspondence) $\square$ apontes@uco.es 


\section{Contribution of this paper to the literature}

- This study demonstrates that there are no significant differences between Science and Technology preservice Secondary Education teachers as regards the construction and development of the TPI.

- It highlights the need to rethink initial Secondary Education teacher training in order to incorporate the development of the TPI into the curriculum so as to improve teaching quality.

- It goes one step further by evincing gender differences in the construction of TPI during pre-service teacher training.

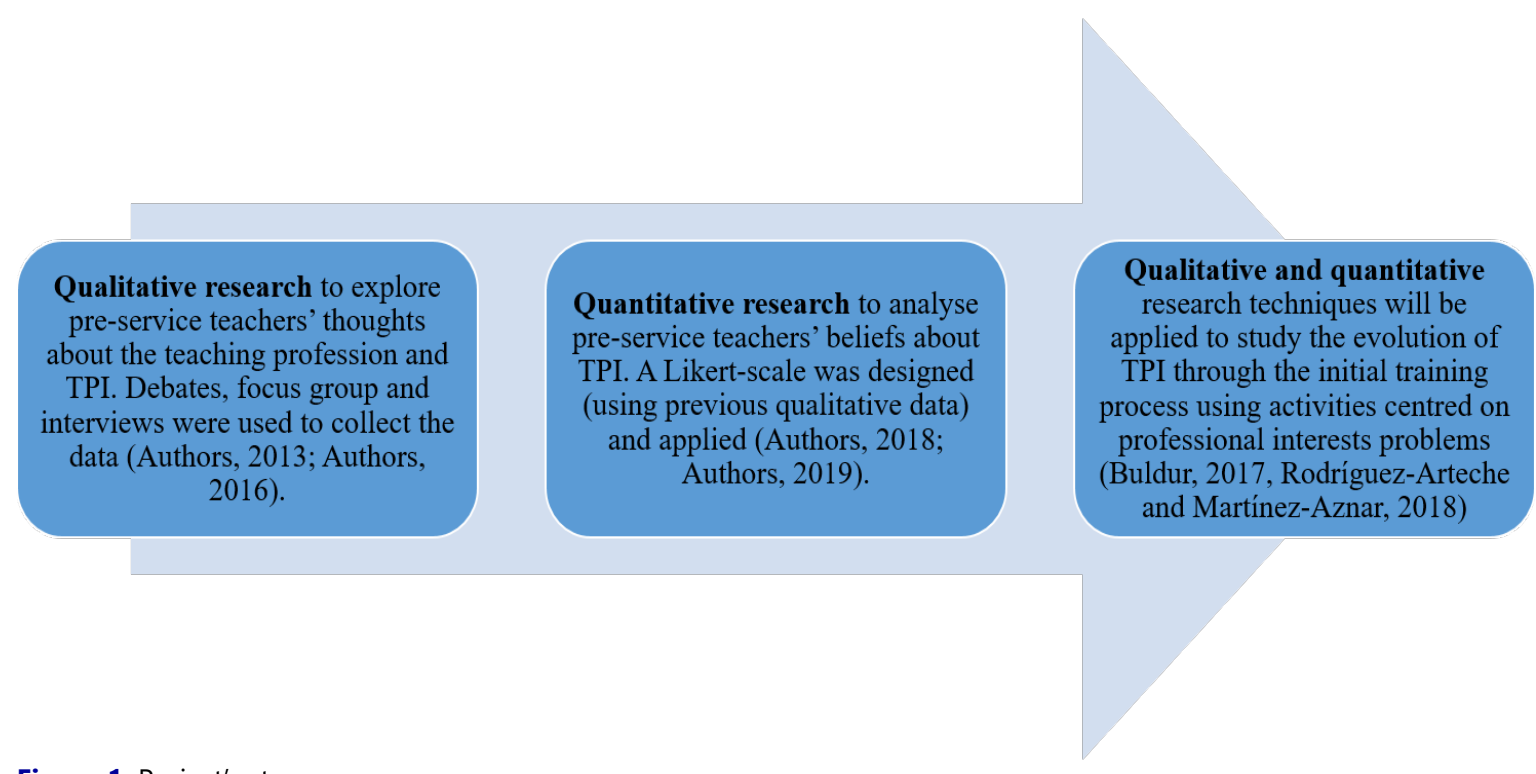

Figure 1. Project's stages

regarding the construction and development of the TPI at the beginning of the training process and what training implications are derived from the knowledge of such characteristics?

To address this problem, the following aspects will be analysed in a differentiated way: (1) The convergence or dissimilarity between Science and Technology future teachers' beliefs on TPI; (2) The degree of extension these beliefs common to the entire sample; (3) The global dimensions in which such beliefs can be grouped and the differences existing in such dimensions or in the items of the scale that can explain such differences.

The theoretical framework of this study and the educational foundation of the global research project is based on ideas from the constructivist and reflexive approach. On the one hand, the constructivist educational approach considers that teachers' beliefs and conceptions about the educational process and the teaching profession mean an important aspect to be taken into account in the initial formation, since there is empirical evidence that future teachers tend to reproduce the action schemes of traditional teaching that they have known as students (Appleton \& Asoko, 1996; Demirci, 2015; Luft, Roehrig, \& Patterson, 2003). Therefore, training strategies should be developed so as to favour the change in the previous conceptions or the evolution of the implicit theories of the teaching staff towards a teaching model oriented to encourage the construction of significant knowledge of their students (Buldur, 2017; Pool, Reitsma \& Mentz, 2013). On the other hand, the reflective approach to teacher education (Abell, Bryan \& Anderson, 1998), which has had a great influence on the proposals for improving teacher training in Science and Technology, devotes great importance to the design and development of activities that allow reflection on different aspects related to the teaching practice and the promotion of metacognition in teacher training (Jiménez-Tenorio \& Oliva, 2016; Pilitsis \& Duncan, 2012; Sutton, 2011). Both approaches contain ideas that serve as a basis for the elaboration of the theoretical framework of this research project. Likewise, these approaches converge with other lines of work focused on advancing towards Desirable Professional Practical Knowledge (Solís, Martín, Rivero, \& Porlán, 2013) or on the Development of effective teaching competences (García-Carmona, 2013), because they also grant importance to reflection and debate on practical problems of interest to teachers, which allow to express their beliefs about the teaching profession and favour the evolution of their personal conceptions of educational processes (Rodriguez-Arteche \& Martínez-Aznar, 2018).

The requirements proposed as regards the role played by Secondary Education teachers has led to an interesting debate about the skills that trainee teachers should acquire and develop, highlighting the need to tackle the construction of the Teacher's Professional Identity (TPI) during this formative period in order to help train more 
competent teachers who will identify more with and be more committed to their profession (Manso Ayuso \& Martín Ortega, 2014; Shatunova, Merzon, Shaimardanova, \& Shabalin, 2018; Zhang, Liu, Yang, Tripp, \& Shao, 2018). The research concerning Science and Technology teachers' beliefs, which has been developed to a fairly considerable extent in the last two decades (Luft, Roehrig, \& Patterson, 2003; Gullberg, Kellner, \& Attorps, 2008; Subramaniam, 2013), has highlighted the important role played by trainee teachers' initial conceptions and beliefs regarding various aspects of the activity of teaching professionally (Buldur, 2017; Pontes Pedrajas, Serrano Rodríguez \& Poyato, 2013; Pool, Reitsma, \& Mentz, 2013; Sutton, 2011) and its relationship with the development of the TPI (Cameron \& Grant, 2017; Smith \& Darfler, 2012), a relatively new term in the field of scientific-technical education that has opened up interesting work perspectives (Izadinia, 2016). In this sense, current research in this topic highlights diverse variables and constructs that directly affect the construction and development of TPI such as the way future teachers understand the profession, the ability to teach and to integrate ICT in the classrooms, their attitude (sensible and self-critic) as well as their interest in engaging students in the teaching-learning process (Izadinia, 2015; Taylor \& Booth, 2015). Moreover, other studies point out that there may be differences in the construction of TPI depending on the stage teachers work (Jarauta Borrasca, 2017; Pontes, Serrano, \& Poyato, 2013). Finally, variables that affect this process can be both individual and contextual (Beijaard, Meijer, \& Verloop, 2004). Therefore, they all have been considered for this study since it would be interesting to test to what extent these constructs affect TPI.

The current situation has led us to ponder the need to provide professionals who are prepared in accordance with present-day teaching needs. It is, therefore, vital to emphasize the importance of profiling the professional identity of teachers themselves, i.e. "to specify what professional roles I am going to assume as a teacher, what could be realistic objectives in my daily work, ... and I should also profile my own style in a manner that is appropriate for my personality and my own ideas about teaching." (Esteve, 2009, p. 20). Otherwise, teachers may fail professionally at an early stage in their career, which will have a direct effect on the quality and excellence of their teaching, and consequently, on their pupil's results at that educative level.

\section{LITERATURE REVIEW}

\section{Science and Technology Pre-service Teachers' Understanding of the Construction and Development of TPI}

Numerous studies regarding educational beliefs have shown that teachers from the area of Science and Technology have ideas, attitudes and motivations concerning teaching, learning and other aspects of education that have an important influence on the construction of the professional knowledge required in order to teach (Alabdulkareem, 2016; Kind, 2016; Shatunova, et al., 2018; Solís, Martín, Rivero, \& Porlán, 2013; Taylor \& Booth, 2015).

In this respect, Asensio and Ruiz (2017) point out that on those degrees that qualify students to work in the teaching profession, the beliefs that these students have regarding what teaching is, how we teach and how we learn, or what the teacher's role is in the context of present-day education, play an important role in their training. The same authors are of the opinion that these beliefs may have an influence on the students' later identification with the teaching profession and the decisions that they will make concerning the methods and resources that they will use during their teaching practice (Buldur, 2017; Rodríguez-Arteche \& Martínez-Aznar, 2018; Subramaniam, 2013). Another study on the teaching beliefs of future teachers when undergoing their initial training that was carried out by Monroy and Hernández Pina (2014) indicates that epistemological beliefs about professional teaching knowledge, teaching and learning processes, educative methods and the teacher's work in general, have an influence on how those students who wish to become teachers in the future learn.

There are also studies that stress the need to take into account Science and Technology teachers' beliefs when they are undergoing their initial permanent training, particularly as regards attempting to improve their teaching practice and bringing the educational context closer to the daily reality of the classroom (Bakar, 2006; El-Deghaidy, Mansour, Aldahmash, \& Alshamrani, 2015). The teaching resources and strategies in the domain of Science and Technology are highly diverse and undergo progressive changes, such that researchers in the field of education attempt to analyse the influence of teachers' beliefs on the use of these resources and strategies in the teaching process carried out in the classroom (Demirci, 2015).

\section{Factors that Influence the Construction and Development of TPI}

The construction of the TPI in relation to future secondary education teachers' initial training has been the focus of interest of various pieces of research carried out in the last decade (Buldur, 2017; Huu \& Ngoc, 2017; Izadinia, 2015; Martínez de la Hidalga \& Villardón-Gallego, 2015). In this respect, some studies stress the role played by the students' process of identifying with the teaching profession and the development of attitudes or values that may 
be important if they are to progress in their professional development (Beijaard, et al., 2004; Esteve, 2009; Timostsuk \& Ugaste, 2010), such as their intrinsic vocation for teaching, a commitment to improving education, the capacity to reflect and be self-critical, the flexibility to adapt to changes and the need to improve their own theoretical and practical training (Hong, 2010; Kim, 2013; Salazar Noguera \& McCluskey, 2017).

The majority of the aforementioned studies concern the sphere in general, and very few tackle the development of the Teacher's Professional Identity (TPI) in the context of the training of Science and Technology teachers, although several works dealing with this subject have been published recently (Avraamidou, 2014; Cameron \& Grant, 2017; Green, 2015; Izadinia, 2016; Smith \& Darfler, 2012; Trevallion, 2018) and it is, therefore, appropriate to analyse them in some detail.

\section{Contextual factors}

The work carried out by Avraamidou (2014) provides an interesting review of the theme of Science teachers' identity through the analysis of 29 previous studies on this subject. In the conclusion, the author emphasizes that future Science teachers already have their own professional identity, which they have been able to forge by means of previous experiences and that evolves as they progress in their teacher training. This author also points out that Science teachers' TPI can be considered to have come about as the result of the combination of their competence and the content domain of the subject, their performance in relation to the scientific experiences that they had before beginning their teacher training and their and others' recognition of them as professionals in the field of science.

Cameron and Grant (2017), meanwhile, interviewed 18 teachers in order to discover the impact of external tutoring on the development of Science teachers' TPI. These authors consider that, in spite of the fact that the TPI of those interviewed began to develop during their initial training process, this professional identity may be affected by the environment in which they work. The results of this study show that there is a direct relationship between training needs and the construction of the TPI. In this respect, they highlight that the external mentoring process may have played a key role in the evolution of the participants' TPI.

Vocational attitudes towards the teaching profession may also play a decisive role in the TPI. In this respect, Green (2015) noted that survey participants' attitudes before starting teacher training were in turn influenced by prior experiences that the majority of them had had in environments other than the sphere of teaching. This author states that "They were more clearly influenced by their prior industry experiences and their vocational attitudes rather than by their teacher education program and their experiences in schools." (Green 2015, p. 55).

Furthermore, one of the factors contributing to the development of the TPI that is most frequently studied is Teaching Practice. Izadinia (2016) concentrated on the importance of this period and the role that professional teachers play as the mentors of new and trainee teachers. This study shows that the construction of the TPI can be considered as a process of negotiating the various concepts of teaching and that the trainees' TPI is enriched upon interacting with working teachers. The mentors interviewed in this study stated that they noticed changes in the trainees as regards aspects such as their teaching strategies, their authority, their confidence and their relationships with the pupils. Trevallion (2018) similarly shows the influence of initial training on the development of the TPI, along with coming into contact with the professional reality (the classroom) and the interpersonal relationships that occur in a work environment.

\section{Independent and individual factors}

Finally, there are also studies which state that there may be other issues than these factors themselves that affect the TPI. On the one hand, Smith and Darfler (2012) state that, in order to become an efficient Secondary Education Science teacher, in addition to forging one's own TPI, it is necessary to know the identity and evolution of one's pupils, along with having an interest in the teaching-learning process. On the other hand, there are independent factors, such as sex or age, that may influence the way in which teachers construct their TPI (Chang \& Lo, 2016).

Gender differences have been determinant in aspects related to professional identity (Allard, 2004; Camacho, 2014; Chetcuti, 2009; Kapitanoff \& Pandey, 2017). Some studies note that the differences between genders in the sphere of teaching influence teachers' vocational attitudes, although Monroy and Hernández (2014) point out that there is still no clear evidence regarding the effect that gender has on the construction of the TPI. However, a study by Blinova (2010) shows that men and women are different in very many respects (personality, conduct, communication, attitude towards conflicts...) and it may, therefore, be interesting to analyse the possible dissimilarities between future male and female teachers as regards the construction of their identity as teachers during the period of their initial training.

Bearing in mind all the advances made in literature in this respect, and given the importance of this subject, we are developing a research project that is oriented towards exploring future Secondary Education Science and Technology teachers' views of the TPI and the factors that influence the process of identifying with the teaching 
profession. In the first phase of this project, we carried out a qualitative study in which we analysed the opinions of a group of SEMD students from the areas of Science and Technology, which were obtained using a set of open questions that formed part of the classroom activity programme in a subject of a specific module on the aforementioned Master's degree (Serrano Rodríguez \& Pontes Pedrajas, 2016). In the second phase we have developed a new study, whose results are shown in this work, in which we have attempted to explore this line of research in greater depth using new investigation instruments and techniques with a view to discovering how future teachers develop the TPI construction process, and what the implications of this process are, in order to improve the quality of Secondary Education Science and Technology teacher's initial training. Within the general framework, our intention with the development of this study is to focus on exploring future Science and Technology teachers' beliefs regarding the global notion of the TPI by first analysing the similarities and differences between students specialising in Science (Physics-Chemistry and Biology-Geology) and those from the sphere of technologycomputing (Technology) with regard to this subject. This is done in order to subsequently study the extent of the principal beliefs comprising the notion of the TPI and the factors that may influence possible differences among the various dimensions on the scale employed.

\section{METHODOLOGY}

\section{Objectives}

To address the different aspects that make up the research problem from an analytical perspective, the following objectives are stated:

- $\quad$ To identify the similarities and differences between SEMD students specialising in Experimental Science and those from the area of Technology as regards: their global idea of TPI, their development in teaching at different educational stages, the relationship between the TPI and the professional identity of other professionals and the aspects that contribute towards the construction of the TPI during their initial teacher training.

- $\quad$ To analyse the extent of the participants' beliefs concerning the construction and development of the TPI.

- To discover whether there are any significant differences among the four dimensions on the scale: (i) the definition of the TPI, (ii) the development of the TPI by teachers in different stages of education, (iii) the TPI and the professional identity of other professionals, and (iv) the aspects that contribute towards the construction of the TPI, by analysing which factors and items are responsible for them.

\section{Instrument}

We have developed this research by designing a questionnaire on the basis of the results obtained in the qualitative study mentioned previously (Serrano Rodríguez, Pérez Gracia \& Pontes Pedrajas, 2018). This quantitative scale was designed because it was tested that there was not any validated tool to analyse TPI. The 'STPI' is formed of 40 variables and split into two sections, the first of which obtains information regarding 9 independent variables related to various socio-demographic data. The second section corresponds to a five-point Likert scale with response options varying from 1 (totally disagree) to 5 (totally agree). It comprises 31 items organised in four dimensions related to the following respective aspects: elements that globally characterise or define the TPI (15); the development of the TPI in different stages of education (5); differences in the way in which teachers and other professionals construct their professional identity (5), and the aspects that contribute towards the development of the TPI (6).

The global questionnaire was validated externally (for its content validity) by a group of five experts in educational research, who evaluated the relevance, pertinence, intensity, clarity and exhaustiveness of the questions on the scale (Oluwatayo, 2012). It was also validated internally (for its construct validity) by applying exploratory and confirmatory factorial analysis techniques. The results of these analysis showed both the high level of sampling adequacy and the significance of the four factors (dimensions) that explain $40 \%$ of the variance. In order to study the reliability of the questionnaire, we calculated the Cronbach's alpha coefficient and obtained a value of 0.879 , which is considered to be sufficiently high, thus demonstrating that the scale is reliable.

\section{Participants}

For this study, the participants were a total of 279 students from four consecutive academic years (2014-2018), of which $51.6 \%$ were women and the remaining $48.4 \%$ were men. It represents $97 \%$ of the population (all students enrolled in the SEMD during the four academic years). Therefore, the sample is made up of those Science and Technology pre-service teachers that attended the lesson in which the scale was administrated, and they voluntarily answered the scale (S-TPI). Since we aimed at getting as many participants as possible so as to ensure a maximum 
of representativeness, the sampling technique applied was the convenience sampling (Emerson, 2015) since participants are selected based on availability and willingness to take part.

The average age of the sample was 26.8 . The majority of the participants were from the University of XXX (78\%), while $13 \%$ were from other universities in XXX,7\% were from other universities in Spain and $2 \%$ were from universities in other countries. The sample was composed of a first group of students from the area of Science (henceforth G1), comprising 54 from the specialities of Physics and Chemistry, and 101 students from the specialities of Biology and Geology, and a second group of students the from the technology-computing sphere (henceforth G2), comprising 58 students from the speciality of Technology and 66 students from the speciality of Computing. A comparative analysis of the Technology and Computing students' beliefs regarding the TPI was carried out in a prior research phase, and no significant differences were found as regards any of the items on the questionnaire, and we, therefore, considered that the students from this technology-computing area formed a homogeneous subset (G2). We also carried out a similar study of the students from the specialities of PhysicsChemistry and Biology-Geology, and since there were no significant differences in the various items on the questionnaire, we also included all the students from the area of experimental science in the same group - G1 (Serrano Rodríguez, Pérez Gracia \& Pontes Pedrajas, 2018).

\section{Research Procedure}

First of all, the researchers of this study asked the University and the professors of the SEMD for permission to carry out this investigation. The data employed in this study were collected at the beginning of the specific module of the SEMD at the University of Córdoba (Spain) in the subject of Complements to Disciplinary Training, which includes a theme regarding teachers' professional profiles, so it addresses contents focused on the teacher professional profile as well as the access to the teaching profession. This subject is taught during the month of October, so it was when data were collected. Moreover, for this module, the SEMD students are separated in groups depending on their field of knowledge.

Students answered voluntarily to the scale and they were informed of the purpose of the study as well as the anonymity of their answers. Answering the scale (S-TPI) took approximately fifteen minutes to each participant.

\section{Data Analysis}

After collecting the data, we applied various statistical treatments to them in order to provide responses concerning the objectives of the present study.

First, in order to analyse the common aspects and the differences between the experimental science group (G1) and that of technology (G2), we applied the parametric student's t-test to each of the variables of the instrument used (objective 1).

We then applied several descriptive analysis procedures (mean values and frequencies) in order to study the extent of the participants' beliefs regarding the aforementioned aspects (objective 2).

To be able to analyse whether there were significant differences between those from the Science and Technology groups as regards the various dimensions on the scale, we applied the Kruskal Wallis test and a pairwise analysis (objective 3). We then used a Permutational Multivariate Analysis of Variance (PERMANOVA,) (objective 3). This analysis made it possible to evaluate the differences among the values of the responses according to the following variables: sex (2 levels) and age (4 levels). We employed the type III square sum, since it is appropriate in the case of an unbalanced design. All the tests were carried out with 9999 permutations with the objective of increasing the power and precision of the analysis of residues with a reduced model (Anderson and Ter Braak, 2003). The advantage of the permutation method is that the resulting test is 'distribution free' and is not limited by many of the suppositions typical of parametric statistics (Walters and Coen, 2006).

Finally, we also carried out an analysis in order to calculate the percentages of similarity/dissimilarity (SIMPER, Similarity Percentages, Clarke, 1993) between the two levels of the sex factor. This analysis enabled us to determine which items were responsible for the greatest proportion of differences among the variables on the questionnaire that the PERMANOVA determined as being significant (sex). In this study, the SIMPER was used to identify and order the items that were responsible for the dissimilarity between the two levels of the sex variable.

The analyses were carried out using the PRIMER V6 computer programme, including the complementary PERMANOVA + package (Anderson, 2008) and the SPSS V22 statistics package.

\section{RESULTS}

This section presents the results according to the four objectives of the study. 
Table 1. Comparison of means of the two groups in the 31 items

\begin{tabular}{|c|c|c|c|c|c|}
\hline Sim. & Item & G1 & G2 & $\mathbf{t}$ & $\mathbf{p}$ \\
\hline 1 & 1. Having an adequate capacity to teach & 4.07 & 4.24 & -1.611 & 0.108 \\
\hline 1 & 2. Feeling a high level of commitment to the teaching profession & 4.33 & 4.35 & -0.208 & 0.835 \\
\hline 1 & 3. Having solid training regarding Education and teaching & 3.99 & 3.86 & 1.290 & 0.198 \\
\hline 1 & 4. Building a positive self-image as an aspiring teacher & 3.93 & 3.69 & 1.876 & 0.062 \\
\hline 1 & 5. Knowing how to adapt yourself to educational changes according to the circumstances & 4.34 & 4.31 & 0.370 & 0.711 \\
\hline 1 & 6. Using and mastering teaching communication techniques & 4.41 & 4.26 & 1.787 & 0.075 \\
\hline 1 & 7. Showing an interest in knowing and understanding students & 4.62 & 4.50 & 1.534 & 0.126 \\
\hline 1 & 8. Integrating ICT into teaching & 3.97 & 3.98 & -0.135 & 0.893 \\
\hline 1 & 9. Properly combining theory and practise about teaching & 4.34 & 4.30 & 0.395 & 0.693 \\
\hline 1 & 10. Worrying about human relationships in the educational context & 4.30 & 4.22 & 0.885 & 0.377 \\
\hline 1 & 11. Ability to manage class work and solve possible conflicts & 4.45 & 4.36 & 1.011 & 0.313 \\
\hline 1 & 12. Having high self-esteem as a teacher & 4.11 & 4.04 & 0.664 & 0.507 \\
\hline 1 & 13. Being an expert in one's discipline & 4.16 & 4.29 & -1.327 & 0.186 \\
\hline 1 & 14. Motivation to awaken the students' interest in learning & 4.65 & 4.69 & -0.478 & 0.633 \\
\hline 1 & 15. Adopting a reflective and self-critical attitude with regard to teaching & 4.43 & 4.45 & -0.319 & 0.750 \\
\hline 2 & 16. The previous academic training to become a teacher is different at each stage & 3.72 & 3.52 & 1.409 & 0.160 \\
\hline 2 & 17. There is a different Curriculum for each educational level & 3.94 & 3.78 & 1.238 & 0.217 \\
\hline 2 & 18. The methodological strategies and resources vary according to the circumst & 4.06 & 3.98 & 0.703 & 0.483 \\
\hline 2 & 19. The problems of coexistence are more frequent in Secondary Education & 3.95 & 3.89 & 0.462 & 0.645 \\
\hline 2 & 20. There are different teaching functions in each stage & 3.96 & 3.61 & 2.403 & 0.067 \\
\hline 3 & 21. Psycho-pedagogical training is required for the teaching profession & 4.05 & 4.02 & 0.302 & 0.763 \\
\hline 3 & 22. Teaching includes an educational practice that makes it different fror & 4.04 & 4.04 & -0.014 & 0.989 \\
\hline 3 & $\begin{array}{l}\text { 23. Teaching implies a relationship with students that contributes to their personal and } \\
\text { academic development }\end{array}$ & 4.43 & 4.35 & 0.774 & 0.439 \\
\hline 3 & $\begin{array}{l}\text { 24. Teaching places a different importance on the interpersonal relationships in the } \\
\text { workplace }\end{array}$ & 3.97 & 3.98 & -0.068 & 0.946 \\
\hline 3 & 25. Teaching fulfils a very specific social mission which differs from that of other professi & 4.14 & 4.21 & -0.595 & 0.552 \\
\hline 4 & 26. Longer placement period & 4.04 & 3.91 & 0.984 & 0.326 \\
\hline 4 & 27. A broader psycho-pedagogical training during the Master's Degree & 3.91 & 3.64 & 2.009 & 0.056 \\
\hline 4 & 28. The recognition and social evaluation of the teaching profession & 3.90 & 3.85 & 0.406 & 0.685 \\
\hline 4 & 29. The acquisition of new methodologies and the use of educational resources & 3.89 & 4.11 & -1.795 & 0.074 \\
\hline 4 & 30. Learning through experiences with other teaching professionals & 4.31 & 4.36 & -0.523 & 0.602 \\
\hline 4 & 31. The promotion of teacher motivation and the develop & 4.23 & 4.23 & 0.000 & 1.000 \\
\hline
\end{tabular}

\section{Similarities and Differences between G1 and G2 as Regard the Construction and Development of the TPI}

After applying the T test in order to study the possible differences between G1 (Science pre-service Secondary Education teachers) and G2 (Technology pre-service Secondary Education teachers) as regards the 31 items on the scale, we observed that there were no significant differences in their responses (Table 1). It means that Science and Technology pre-service Secondary Education teachers understand TPI construction and development in the same terms.

The items in which the difference between G1 and G2 is greater are those related to the ability to solve problems in the classroom (item 11), the idea that the previous academic training to become a teacher is different at each stage (item 16), the importance of the relationship between the teacher and the students (item 23), the need to broaden the psycho-pedagogical training (item 27) and the importance of knowing new methodologies and teaching resources (item 29). On the other hand, the items with no difference or slight difference between both groups have to do with the inclusion of ICT in lesson planning (item 8), the fact that teaching includes an educational practice that makes it different from other professions (item 22), the relevance of interpersonal relationships in this profession (item 24) and the role of motivation and the development of a professional project (item 31). Therefore, since there are not statistically significant differences between G1 and G2 in regard to the items of the scale S-TPI, the sample is considered as a unique group for the following analyses.

\section{Extent of Principal Beliefs}

An analysis of the frequency and means was carried out in order to analyse the extent of the beliefs of the groups surveyed (Figure 2). 


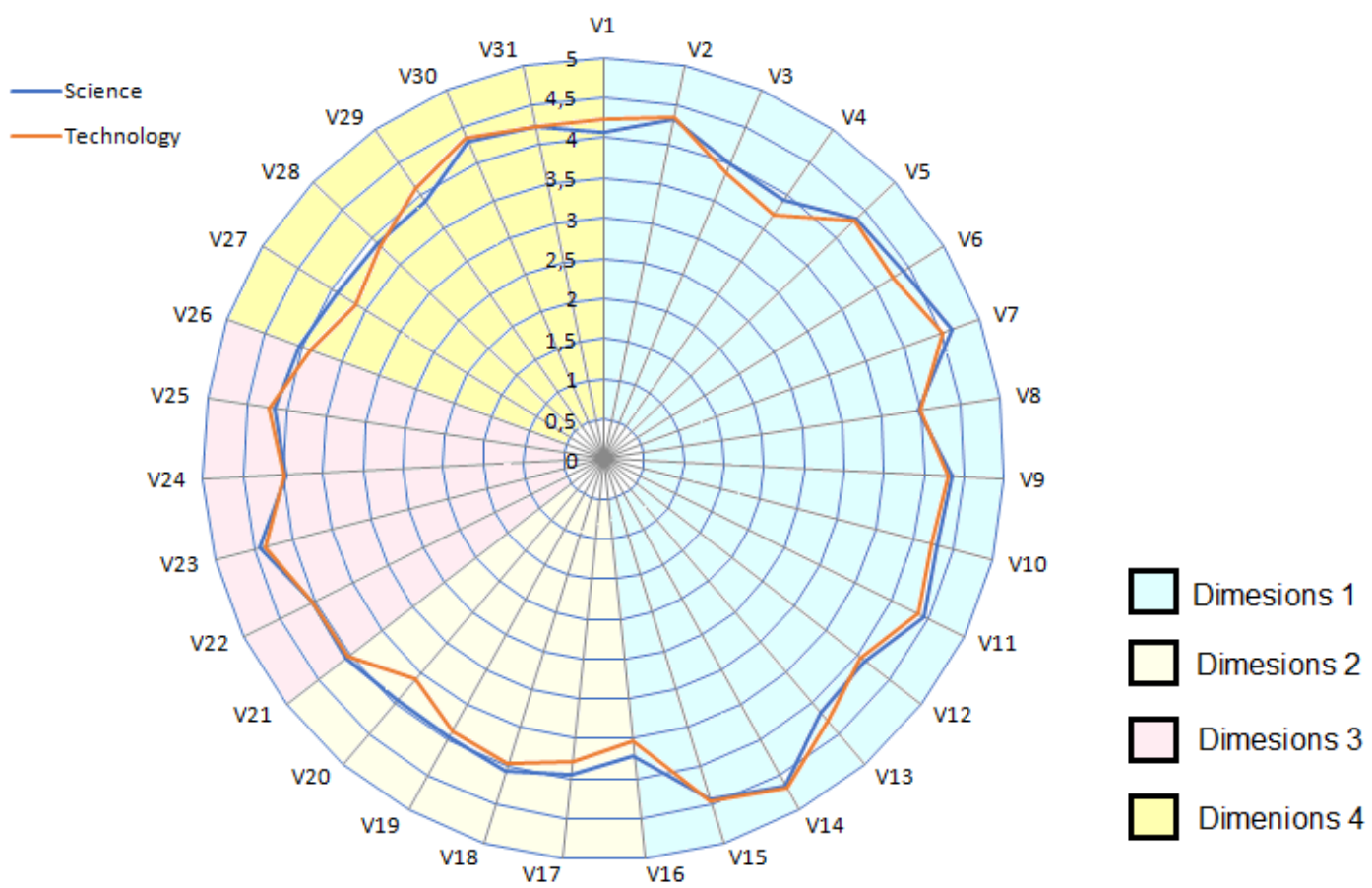

Figure 2. Extent of beliefs regarding TPI

The items with the highest frequency in dimension 1 (definition of the TPI) and which, therefore have the highest rate of agreement, are related to motivating the pupil during the teaching-learning process (item $14, \bar{x}$ $=4.67$ ), showing an interest in understanding the pupils and their needs (item $7, \bar{x}=4.55$ ) and having classroom management skills and the ability to resolve possible conflicts that occur on a daily basis (item $11, \bar{x}=4.41$ ). The items with the lowest frequency were, however, those related to constructing a positive image of oneself as a teacher (item $4, \bar{x}=3.81$ ) and integrating information and communication technologies into the classroom (item 8, $\bar{x}=3.97$ ).

The frequencies of the responses were lower in dimension 2 (developing the TPI in the different stages of education) because there was a lesser degree of agreement among them. The sample shows that the development of the TPI differs in the different stages of education because the curriculum is different (item $17, \bar{x}=3.86$ ) and because different methodological strategies and resources are required depending on the stage (item $18, \bar{x}=4.02$ ). However, the participants did not consider that receiving different prior academic training has an influence on the development as their identity as teachers (item $16, \bar{x}=3.62$ ).

The frequencies in dimension 3 (differences in the way in which teachers and other professionals construct their professional identity) were once again high. These differences are associated with the fact that teaching implies a relationship with the pupils that contributes to both their academic and personal development (item 23, $\bar{x}=4.39$ ). They are also related to the interpersonal relationships with workmates (item $24, \bar{x}=3.98$ ), although with much less frequency.

The most relevant aspects in dimension 4 (aspects that contribute to the development of the TPI) are learning through experience (item $30, \bar{x}=4.33$ ), the teachers' motivation and vocation (item $31, \bar{x}=4.23$ ) and the periods of teaching practice in initial training, during which trainee teachers have the opportunity to be immersed in the real context of a classroom (item $26, \bar{x}=3.97$ ). The acquisition of new methodologies and the use of educational resources (item $29, \bar{x}=4$ ) have a lower frequency in this dimension.

\section{Study of Differences among Dimensions and Factors Responsible for Such Differences}

To develop the third objective of the study, it is necessary to go from the "micro" level, based on the analysis of the specific beliefs reflected in each item of the scale, to the "macro" level that requires an analysis of the overall results obtained in the four dimensions of the scale that refer to the following aspects: understanding of TPI, development of the TPI in the teaching staff of different educational levels, relationship between the professional identity of teachers and that of other professionals and aspects that contribute to the construction of TPI during initial training. 
Table 2. Results of PERMANOVA according to sex and age

\begin{tabular}{ccccc}
\hline Variables & $\boldsymbol{g l}$ & $\boldsymbol{S c}$ & $\boldsymbol{F}$ & $\boldsymbol{p}$ \\
\hline Sex & 1 & 513.02 & 4.72 & $0.001^{*}$ \\
\hline Age & 2 & 177.13 & 0.81 & 0.72 \\
\hline Sex*Age & 2 & 253.73 & 1.16 & 0.25 \\
\hline Residues & 273 & 29698 & & \\
\hline Total & 278 & 30606 & & \\
\hline
\end{tabular}

Table 3. Contribution of each of the items to the dissimilarity between men and women

\begin{tabular}{|c|c|c|c|c|c|c|}
\hline \multicolumn{7}{|c|}{ Average dissimilarity $=11.83 \%$} \\
\hline & & G1 & G2 & & & \\
\hline Dim. & Item & Mean & Mean & Average dis. & $\%$ Contr. & $\%$ Accum. \\
\hline 2 & 20 & 3.78 & 3.83 & 0.52 & 4.41 & 4.41 \\
\hline 2 & 16 & 3.60 & 3.65 & 0.51 & 4.29 & 8.69 \\
\hline 4 & 28 & 3.76 & 4.01 & 0.50 & 4.19 & 12.89 \\
\hline 4 & 27 & 3.99 & 3.58 & 0.49 & 4.17 & 17.06 \\
\hline 2 & 19 & 3.97 & 3.87 & 0.47 & 3.95 & 21.01 \\
\hline 2 & 17 & 3.96 & 3.78 & 0.45 & 3.83 & 24.84 \\
\hline 4 & 26 & 4.09 & 3.87 & 0.45 & 3.83 & 28.67 \\
\hline 1 & 4 & 3.88 & 3.77 & 0.45 & 3.78 & 32.46 \\
\hline 4 & 29 & 4.10 & 3.87 & 0.44 & 3.74 & 36.20 \\
\hline 1 & 8 & 4.10 & 3.84 & 0.43 & 3.59 & 39.79 \\
\hline 3 & 24 & 4.03 & 3.91 & 0.42 & 3.52 & 43.32 \\
\hline 2 & 18 & 4.19 & 3.84 & 0.41 & 3.50 & 46.81 \\
\hline 3 & 21 & 4.24 & 3.81 & 0.41 & 3.47 & 50.28 \\
\hline 3 & 22 & 3.99 & 4.09 & 0.40 & 3.38 & 53.66 \\
\hline 3 & 25 & 4.14 & 4.21 & 0.39 & 3.31 & 56.97 \\
\hline 1 & 1 & 4.23 & 4.06 & 0.37 & 3.14 & 60.11 \\
\hline 4 & 31 & 4.28 & 4.16 & 0.37 & 3.13 & 63.24 \\
\hline 1 & 12 & 4.12 & 4.04 & 0.36 & 3.08 & 66.32 \\
\hline 1 & 3 & 4.07 & 3.79 & 0.36 & 3.06 & 69.38 \\
\hline 4 & 30 & 4.36 & 4.30 & 0.34 & 2.87 & 72.25 \\
\hline 1 & 10 & 4.38 & 4.14 & 0.34 & 2.85 & 75.10 \\
\hline 1 & 13 & 4.24 & 4.19 & 0.34 & 2.84 & 77.94 \\
\hline 1 & 5 & 4.47 & 4.17 & 0.33 & 2.83 & 80.76 \\
\hline 1 & 9 & 4.42 & 4.21 & 0.32 & 2.68 & 83.44 \\
\hline 3 & 23 & 4.51 & 4.27 & 0.31 & 2.61 & 86.05 \\
\hline 1 & 6 & 4.47 & 4.21 & 0.30 & 2.53 & 88.58 \\
\hline 1 & 11 & 4.53 & 4.28 & 0.30 & 2.51 & 91.09 \\
\hline
\end{tabular}

Therefore, we first carried out the Kruskal Wallis test, which indicated that there were significant differences among the four dimensions on the scale $(\mathrm{H}=74.52 ; \mathrm{p}<0.0001)$. Furthermore, the pairwise test confirmed that there were differences among the four dimensions $(\mathrm{p}<0.05)$.

Finally, after verifying that there were significant differences among the four dimensions on the scale, we studied which factor and which items were most responsible for these differences. We included both independent variables of the scale (sex and age) so as to check which on was responsible for the existing difference (Table 2).

PERMANOVA results show that the independent variable sex significantly affects the way participants respond to the items of the scale in the four dimensions (men and women respond differently) $(\mathrm{F}=4.72, P=0.001)$. However, there are no significant differences as regards either the age factor $(F=0.81, P=0.72)$ or the interaction between sex and age $(F=1.16, P=0.25)$.

The results of the SIMPER analysis (Table 3) indicate an average amount of dissimilarity, as regards the evaluation of the responses, of $11.83 \%$ between men and women. This difference is principally owing to the following items: 20 (4.41\%) "There are different teaching functions in each stage", 16 (4.29\%) "The previous academic training to become a teacher is different at each stage", 28 (4.19\%) "The recognition and social evaluation of the teaching profession", 27 (4.17\%) "A broader psycho-pedagogical training during the Master's Degree" and 19 (3.95\%) "The problems of coexistence are more frequent in Secondary Education". We should stress that all of these items belong to dimension 2 , with the exception of item 28 , which is from dimension 4. 


\section{DISCUSSION AND CONCLUSIONS}

This paper analyses SEMD Science and Technology students' beliefs regarding the construction of the TPI during their initial teacher training process. We have first studied the similarities and differences as regards this subject between students from the area of Science and those from the area of Technology and have then gone on to analyse the extent of the principal beliefs of which the idea of the TPI is composed, along with the factors that may influence the origin of any possible differences. This was done using a Likert scale test created using the opinions on this subject obtained in a prior stage by means of open questions (Serrano Rodríguez \& Pontes Pedrajas, 2016). We verified $a$ priori that the new questionnaire had appropriate reliability and validity features for a research instrument (Serrano Rodríguez, Pérez Gracia \& Pontes Pedrajas, 2018).

With regard to the first objective, a broad degree of similarity has been observed in the Science and Technology future teachers' beliefs regarding the global understanding of TPI. It also happens with respect to the development of the TPI in the teaching staff of different educational stages and around the relationship between the TPI and the professional identity of other professionals. There is also convergence of results around the aspects that contribute to the construction of TPI during the initial teacher training. This similarity has also been observed in other previous works related to the beliefs of such groups around various aspects of teaching activity (Solís et al., 2013) and around the teaching processes (Pontes, Poyato, \& Oliva, 2018). These results can be better understood considering that the previous experience as students and the academic training received by such groups is similar during Secondary Education. Regarding the university education of both groups, it is also quite similar at the methodological level, although there are differences in the contents of the teaching of the different scientific and technological degrees.

In the case of the second objective, upon considering that both groups form part of the same sample, we observed that the S\&T SEMD students extensively relate the general idea of the TPI with the possession of a series of qualities that are of particular interest for those who wish to work in the teaching profession (an interest in learning from the pupils, commitment to education, professional self-esteem, the capacity to adapt to changes, the importance of teacher training, concern about the human relationships that occur in educational contexts, the capacity for reflexion and self-criticism, etc.). In this respect, the results also reflect the importance of acquiring certain professional skills that are basic for those who wish to teach in secondary education centres (transforming scientific training into didactic knowledge of the content, motivating the pupils to learn Science and Technology, using and dominating educational communication techniques, effectively integrating ICTs into teaching, learning to resolve conflicts and appropriately managing educative processes in the classroom, etc.). Previous works have also shown that these aspects are important elements as regards teaching in an appropriate manner and improving the quality of education (Avraamidou, 2014; Beijaard et al., 2004; Izadinia, 2016; Smith \& Darfler, 2012), and have stressed the importance of the professional being able to maintain the pupils motivated and interested during the teaching-learning process and of developing the specific abilities that are required to be able to teach efficiently.

Other subjects regarding which we have found highly extended beliefs concern the different way in which the TPI is developed by teachers at different levels of teaching. The participants specifically placed quite a lot of emphasis on the fact that both the curriculum and the didactic strategies and resources used by teachers are different according to the stage of education. This is related to the results obtained in the study carried out by Bakar (2016), which indicated that S\&T teachers require specific training, since the didactic content and the teaching strategies have to be adapted to the pupils' level of education.

With regard to the differences in the way in which teachers and other professionals with a university education construct their professional identity, the results obtained in this work show a high level of agreement as regards the opinion that interpersonal relationships in the work context have quite a significant influence in the sphere of education. This is related to the results obtained in other studies that showed the importance of the development of the TPI when trainee teachers come into contact with professionals from the same sphere during their teaching practice and get to know the real context in which they will develop as teachers (Cameron \& Grant,2017; Green, 2015; Trevallion, 2018). Furthermore, the participants in this study indicated that the aspects that have most influence on the construction of the TPI during initial training are the period of teaching practice (Avraamidou, 2014; Izadinia, 2016) and professional interest of a vocational nature (Kim, 2013; Salazar Noguera \&McCluskey, 2017) in order to prevent the burnout of newly-graduated teachers (Hong, 2010).

When summing up the purposes of this study, it is worth recalling that the first two objectives are related to the participants' responses to each of the items on the S-TPI scale. However, in order to develop the third objective, it was necessary to carry out an in-depth global analysis of the results obtained for the four dimensions of which the aforementioned scale is composed.

As for the independent variables, the results obtained in this respect do not reflect differences according to the SEMD students' knowledge area or age in any of these dimensions but do reflect significant differences with regard to their gender in all cases. 
Furthermore, gender is responsible for the differences among the answers given in the four dimensions. The answers in which men and women differ more are mainly related to the factors that affect the development of TPI. Men and women do not agree with the need to increase the placement period, the importance of the psychopedagogic training and the recognition and social approval of the teaching profession so as to enhance their identities as future teachers (Cameron \& Grant, 2017; Huu \& Ngoc, 2017; Izadinia, 2016). Moreover, they also dissent in the fact that different educational stages require dissimilar training since not only the curriculum but also the students present diverse peculiarities (Martínez de la Hidalga, et al., 2015). Finally, their different opinions rely on the fact in order to build TPI it is necessary to have a positive self-image of you as future teachers (Kapitanoff \& Pondey, 2017). This contrasts with the results obtained in previous studies regarding the influence of age (Chang \& Lo, 2016) or gender (Monroy \& Hernández, 2014) on students' initial thoughts about various aspects of the teaching profession. However, the data in this study refer very specifically to their beliefs concerning the construction of the teacher's professional identity and, judging by the results obtained, we have to conclude that the gender variable would appear to play a relevant role in SEMD Science and Technology students' initial ideas about the TPI. We are of the opinion that this may be related to the fact that men and women are globally trained in different ways as regards society and family (Blinova, 2010), or the existence of social stereotypes that indicate a progressive process of feminisation of the teaching profession (Kapitanoff \& Pandey, 2017).

In order to draw conclusions derived from the above results, it is worth remembering that this study is part of a larger project, aimed at fostering reflection on teaching activity and the construction of adequate professional knowledge (Abell et al., 1998; Appleton \& Asoko, 1996; Sutton 2011), which is being developed in three phases and this paper is part of the second stage, focused on analysing the main characteristics of TPI that have been detected through classroom activities in the previous stage (Serrano Rodríguez \& Pontes Pedrajas, 2016). From our point of view, the most relevant fact is that future Science and Technology teachers show a certain interest in the development of the teacher's professional identity from the beginning of their teacher training Master's degrees, and that their view of the TPI is fairly closely related to the need to acquire certain professional skills that are appropriate in order to improve teaching and learning processes in the subjects related to Science and Technology (Avramidou, 2014; Cameron \& Grant, 2017).

In this sense, we must highlight, as a relevant fact, the important relationship that future Science and Technology teachers establish between the construction of the TPI during initial training and the development of teaching skills linked to key elements of the constructivist approach, such as the following: to better understand the needs of students and learn to motivate students during the teaching-learning process, become familiar with new teaching methods based on the use of innovative strategies and interactive resources, take better advantage of the period of teaching practices for acquire skills related to interactive communication and the organization of work in the classroom, trying to learn to solve possible conflicts that arise in the classrooms and secondary schools (García-Carmona, 2013; Pontes Pedrajas, Serrano Rodríguez \& Poyato, 2013). Another interesting aspect of this study refers to the gender differences detected around some beliefs related to the way future Science and Technology teachers build TPI during the initial teacher training. This is an issue that has been little investigated so far, although there are studies that present a good perspective to further explore this aspect (Allard, 2004; Chetcuti, 2009; Camacho, 2014).

All in all, we should highlight the need to bear in mind SEMD students' beliefs regarding teaching and the professional identity when designing the future S\&T teachers' training process with regard to both the academics responsible for this and the professors who give classes on teaching on this Master's degree. In this respect, we consider that it would be appropriate to include the subject of the TPI in the curricular design of the Master's degree, linked to didactic knowledge of the content and the development of the educational curriculum of each speciality (Serrano Rodríguez, Pérez Gracia \& Pontes Pedrajas, 2018).

These facts have led us to design new training proposals for the third phase of the project, based on activities that allow progress in the relationship between the development of teaching professionalism and reflection on educational practice, on the use of innovative strategies for teaching of Science and Technology (inquiry-based and problem solving learning, the use of models in Science, project-based learning, analysis of technological objects, science-technology-society relations, teaching in context, etc.) or on the use of educational resources that encourage student motivation and interaction (analogies, simulations, practical work in the classroom or in the laboratory, interactive response systems using remote controls, etc.). From this perspective, it is necessary that Science and Technology teachers in the initial training period understand the importance of reflecting and debating on practical problems of the teaching profession, during the development of activities that allow to explain their beliefs and favour the evolution of their previous conceptions (Buldur, 2017; Demirci, 2015; Jiménez-Tenorio \& Oliva, 2016; Rodriguez-Arteche \& Martínez-Aznar, 2018). Likewise, taking into account the lower vocation that is appreciated by Secondary Education students when it comes to choosing some Science and Engineering degrees (Lych \& Nowosenetz, 2009), we also think it is necessary to develop classroom activities that help future teachers reflect on 
the incorporation of a gender perspective when planning the teaching of Science and Technology in Secondary Education (Camacho, 2014; Chetcuti, 2009).

Finally, in the following stage of this project, we also intend to extend the reach of this research by carrying out a long-term study in which we shall analyse the changes that take place as regards trainee teachers' views of educative processes and the development of teaching professionalism (Buldur, 2017), from the beginning of their initial training until their teaching practice in secondary education centres. This is owing to the existence of studies that have detected various identity crises as a result of the expectations raised by academic training clashing with the complexity of the educational reality (Esteve, 2009; Smith \& Darfler, 2012).

\section{REFERENCES}

Abell, S. K., Bryan, L. A., \& Anderson, M. A. (1998). Investigating preservice elementary science teacher reflective thinking using integrated media case-based instruction in elementary science teacher preparation. Science Education, 82, 491-510. https:/ / doi.org/10.1002/(SICI)1098-237X(199807)82:4<491::AID-SCE5>3.0.CO;2-6

Alabdulkaree, S. A. (2016). The Impact of Science Teachers' Beliefs on Teaching Science: The Case of Saudi Science Teachers. Journal of Education and Learning, 5(2), 233-249. https:/ / doi.org/10.5539/jel.v5n2p233

Allard, A. C. (2004). Speaking of gender: Teachers' metaphorical constructs of male and female students. Gender and Education, 16(3), 347-363. https:/ / doi.org/10.1080/09540250042000251489

Appleton, K., \& Asoko, H. (1996). A case study of a teacher's progress toward using a constructivist view of learning to inform teaching in elementary science. Science Education, 80(2), 165-180. https:/ / doi.org/10.1002/(SICI)1098-237X(199604)80:2<165::AID-SCE3>3.0.CO;2-E

Asensio, I., \& Ruiz, C. (2017). Medida y evaluación de las creencias sobre la profesión de los maestros en formación. Revista Electrónica Interuniversitaria de Formación del Profesorado, 20(3), 79-91. https:/ / doi.org/10.6018/reifop.20.3.265231

Avraamidou, L. (2014). Studying science teacher identity: current insights and future research directions. Studies in Science Education, 50(2), 145-179. https:/ / doi.org/10.1080/03057267.2014.937171

Bakar, E. (2006). Preservice Science teachers' beliefs about Science-Technology and their implication in society. Eurasia Journal of Mathematics, Science $\mathcal{E}$ Technology Education, 2(3), 18-31. https://doi.org/10.12973/ ejmste/75462

Beijaard, D., Meijer, P. C., \&Verloop, N. (2004). Reconsidering research on teachers' professional identity. Teaching and Teacher Education, 20, 107-128. https:/ / doi.org/10.1016/j.tate.2003.07.001

Blinova, M. L. (2010). Pedagogical conditions of ensuring continuity in development of professional competence of the students and the beginning teachers. Joshkar: Ola.

Buldur, S. (2017). A Longitudinal Investigation of the Preservice Science Teachers' Beliefs about Science Teaching during a Science Teacher Training Programme. International Journal of Science Education, 39(1), 1-19. https:/ / doi.org/10.1080/09500693.2016.1262084

Camacho, J. (2014). Concepciones sobre ciencia y género en el profesorado de Educación Científica desde la perspectiva de género. Creencias del profesorado de Ciencias. Tecné, Episteme y Didaxis: TED, 227-233.

Cameron, D., \& Grant, A. (2017). The role of mentoring in early career physics teachers' professional identity construction. International Journal of Mentoring and Coaching in Education, 6(2), 128-142. https://doi.org/10.1108/IJMCE-01-2017-0003

Chang, C., \& Lo, M. (2016). Exploring inclusive pedagogical practices in Hong Kong primary EFL classrooms. International Journal of Inclusive Education, 21(7), 714-729. https:/ / doi.org/10.1080/13603116.2016.1252798

Chetcuti, R. (2009). Identifying a gender-inclusive pedagogy from Maltese science teachers' personal practical knowledge. International Journal of Science Education, 31(1), 81-99. https:/ / doi.org/10.1080/09500690701647996

Demirci, N. (2015). Prospective high school Physics teachers' beliefs about teaching practices: From traditionalist to constructivists. Eurasia Journal of Mathematics, Science \& Technology Education, 11(3), 693-711. https:/ / doi.org/10.12973/eurasia.2015.1332a

El-Deghaidy, H., Mansour, N., Aldahmash, A., \&Alshamrani, S. (2015). A framework for designing effective professional development: Science teachers' perspectives in a context of reform. Eurasia Journal of Mathematics, Science \& Technology Education, 11(6), 1579-1601. https:/ / doi.org/10.12973/eurasia.2015.1424a

Emerson, R. W. (2015). Convenience sampling, random sampling, and snowball sampling: how does sampling affect the validity of research? Journal of Visual Impairment \& Blindness, 109(2), 164-168. https:/ / doi.org/10.1177/0145482X1510900215 
Esteve, J. M. (2009). La formación de profesores: bases teóricas para el desarrollo de programas de formación inicial. Revista de Educación, 350, 15-29. https:/ / doi.org/10.4438/1988-592X-0034-8082-RE

Flores, M A., \& Day, C. (2006). Contexts which shape and reshape new teacher identities: A multi-perspective study. Teaching and Teacher Education, 22(2), 219-232. https:/ / doi.org/10.1016/j.tate.2005.09.002

García-Carmona, A. (2013). Educación científica y competencias docentes: Análisis de las reflexiones de futuros profesores de Física y Química. Revista Eureka sobre Enseñanza y Divulgación de las Ciencias, 10, 552-567. https:/ / doi.org/10.25267/Rev_Eureka_ensen_divulg_cienc.2013.v10.iextra.05

Green, A. (2015). Teacher induction, identity, and pedagogy: hearing the voices of mature early career teachers from an industry background. Asia-Pacific Journal of Teacher Education, 43(1), 49-60. https:/ / doi.org/10.1080/1359866X.2014.905671

Gullberg, A., Kellner, E. y Attorps, I. (2008). Prospective Teachers' Initial Conceptions about Pupils' Understanding of Science and Mathematics. European Journal of Teacher Education, 31(3), 257-278. https:// doi.org/10.1080/02619760802208429

Hong, J. (2010). Pre-service and Beginning Teachers' Professional Identity and Its Relation to Dropping Out of the Profession. Teaching and Teacher Education, 26(8), 1530-1543. https:/ / doi.org/10.1016/j.tate.2010.06.003

Huu, T., \& Ngoc, H. (2017). Preservice teachers' identity development during the teaching internship. Australian Journal of Teacher Education, 42(8), 1-15. https:/ / doi.org/10.14221/ajte.2017v42n8.1

Izadinia, M. (2015). A closer look at the role of mentor teachers in shaping preservice teachers' professional identity. Teaching and Teacher Education, 52, 1-10. https:/ / doi.org/10.1016/j.tate.2015.08.003

Izadinia, M. (2016). Preservice teachers' professional identity development and the role of mentor teachers. International Journal of Mentoring and Coaching in Education, 5(2), 127-143. https://doi.org/10.1108/IJMCE01-2016-0004

Jarauta Borrasca, B. (2017). La construcción de la Identidad Profesional del Maestro de Primaria durante su Formación Inicial. El caso de la Universidad de Barcelona. Profesorado. Revista de Currículum y Formación del Profesorado, 21(1), 103-122.

Jiménez-Tenorio, N., \& Oliva, J. M. (2016). Análisis reflexivo de profesores de ciencias de secundaria en formación inicial en torno a diferentes secuencias didácticas. Revista Eureka sobre Enseñanza y Divulgación de las Ciencias, 13(2), 423-439. https://doi.org/10.25267/Rev_Eureka_ensen_divulg_cienc.2016.v13.i2.14

Kapitanoff, S., \& Pandey, C. (2017). Stereotype threat, anxiety, instructor gender, and underperformance in women. Active Learning in Higher Education, 1, 1-17. https:/ / doi.org/10.1177/1469787417715202

Kim, D. T. (2013). Idendity in activity: Examining teacher professional identity formation in the paired-placement of student teachers. Teaching and Teacher Education, 30, 47-59. https:/ / doi.org/10.1016/j.tate.2012.10.006

Kind, V. (2016). Preservice Science Teachers' Science Teaching Orientations and Beliefs about Science. Science Education, 100(1), 122-152. https:/ / doi.org/10.1002/sce.21194

Luft, J., Roehrig, G., \& Patterson, N. (2003). Contrasting landscapes: a comparison of the impact of different induction programs on beginning secondary science teachers' practices, beliefs and experiences. Journal of Research in Science Teaching, 40(1), 77-07. https:/ / doi.org/10.1002/tea.10061

Lych, I., \& Nowosenetz, T. (2009). An exploratory study of students' constructions of gender in science, engineering and technology. Gender and Education, 21(5), 567-581. https://doi.org/10.1080/09540250802555424

MansoAyuso, J., \& Martín Ortega, E. (2013). Valoración del Máster de formación de profesorado de EducaciónSecundaria: estudio de casosen dos universidades. Revista de Educación, 364, 145-169. https:/ / doi.org/10.4438/1988-592X-RE-2014-364-258

Martínez de la Hidalga, Z., \& Villardón-Gallego, L. (2015). La imagen del profesor de Educación Secundria en la formación inicial. Profesorado, Revista de currículum y formación del profesorado, 19(1), 452-467.

Monroy, F., \& Hernández Pina, F. (2014). Factores que influyen en los enfoques de aprendizajeuniversitario. Una revision sistemática. Educación XXI, 17(2), 105-124. https:/ / doi.org/10.5944/educxx1.17.2.11481

Oluwatayo, J. A. (2012). Validity and reliability issues in educational research. Journal of Educational and Social Research, 2(2), 391-400.

Pilitsis, V., \& Duncan, R. G. (2012). Changes in belief orientations of preservice teachers and their relation to inquiry activities. Journal of Science Teacher Education, 23(8), 909-936. https:/ / doi.org/10.5901/jesr.2012.v2n2

Pontes Pedrajas, A., Serrano Rodríguez, R., \& Poyato, F. (2013). Concepciones y motivaciones sobre el desarrollo profesional docente en la formación inicial del profesorado de enseñanza secundaria. Revista Eureka sobre Enseñanza y Divulgación de las Ciencias, 10(Nº Extra), 533-551. 
Pool, J., Reitsma, G., \& Mentz, E. (2013). An Evaluation of Technology Teacher Training in South Africa: Shortcomings and Recommendations. International Journal of Technology and Design Education, 23(2), 455-472. https:// doi.org/10.1007/s10798-011-9198-9

Rodríguez-Arteche, I., \& Martínez-Aznar, M. M. (2018). Evaluación de una propuesta para la formación inicial del profesorado de Física y Química a través del cambio en las creencias de los participantes. Revista Eureka sobre $\begin{array}{llllll}\text { Enseñanza } y & \text { Divulgación Ciencias, } & 1601 .\end{array}$ https:/ / doi.org/10.25267/Rev_Eureka_ensen_divulg_cienc.2018.v15.i1.1601

Salazar Noguera, J., \& McCluskey, K. (2017). A case study of early career secondary teachers' perceptions of their preparedness for teaching: lessons from Australia and Spain. Teacher Development, 21(1), 101-117. https:/ / doi.org/10.1080/13664530.2016.1204353

San Román, S. (2010). La feminización de la profesión: identidad de género de las maestras. Revista de Sociología de la Educación, 3(3), 376-387.

Sánchez Vidal, M. S. (2015). El proceso de feminización de la enseñanza. Publicaciones didácticas, 62, 4-11.

Scott, J. (2000). Género e Historia. México: Fondo de Cultura Económica. Universidad Autónoma de la Ciudad de México.

Serrano Rodríguez, R., \& Pontes Pedrajas, A. (2016). Concepciones sobre la identidad profesional docente en la formación inicial del profesorado de ciencias experimentales de Educación Secundaria. Educadi, 1(1), 55-71. https:/ / doi.org/10.7770/educadi-V1N1-art1004

Serrano Rodríguez, R., Pérez Gracia, E., \& Pontes Pedrajas, A. (2018). Creencias sobre la identidad profesional docente en los futuros docentes de ciencias sociales. In E. López-Meneses, D. Cobos-Sanchiz, A.H.Martín Padilla, L. Molina-García \& A. Jaén-Martínez (Eds.) Experiencias pedagógicas e innovación educativa. Aportaciones desde la práxis docente e investigadora (pp. 1411-1426). Barcelona: Octaedro.

Shatunova, O., Merzon, E., Shaimardanova, M., \& Shabalin, S. (2018). Training of future technology teachers: Management tools and challenges in current educational process. Eurasia Journal of Mathematics, Science $\mathcal{E}$ Technology Education, 14(6), 2343-2351. https:/ / doi.org/10.29333/ ejmste/89559

Smith, M., \& Darfler, A. (2012). An Exploration of Teachers' Efforts to Understand Identity Work and its Relevance to Science Instruction. Journal of Science Teacher Education, 23(4), 347-365. https:/ / doi.org/10.1007/s10972012-9281-4

Solís, E., Martín, R., Rivero, A., \& Porlán, R. (2013). Expectativas y concepciones de los estudiantes del MAES en la especialidad de Ciencias. Revista Eureka sobre Enseñanza y Divulgación de las Ciencias, 10 (Extra), 496-513. https:/ / doi.org/10.25267/Rev_Eureka_ensen_divulg_cienc.2013.v10.iextra.02

Subramaniam, K. (2013). Minority Preservice Teachers' Conceptions of Teaching Science: Sources of Science Teaching Strategies. Research in Science Education, 43(2), 687-709. https:/ / doi.org/10.1007/s11165-012-92843

Sutton, S. R. (2011). The Preservice Technology Training Experiences of Novice Teachers. Journal of Digital Learning in Teacher Education, 28(1), 39-47. https:/ / doi.org/10.1080/21532974.2011.10784678

Taylor, D. L., \& Booth, S. (2015). Secondary Physical Science Teachers' Conceptions of Science Teaching in a Context of Change. International Journal of Science Education, 37(8), 1299-1320. https:/ / doi.org/10.1080/09500693.2015.1035356

Timostsuk, I., \& Ugaste, A. (2010). Student teachers' professional identity. Teaching and Teacher Education, 26, 15631570. https:/ / doi.org/10.1016/j.tate.2010.06.008

Trevallion, D. (2018). The changing professional identity of pre-service technology education students. International Journal of Innovation, Creativity and Change, 4(1), 1-15.

Zhang, R., Liu, X., Yang, Y., Tripp, J., \& Shao, B. (2018). Preservice Science teachers' Instructional Design Competence: Characteristics and correlations. Eurasia Journal of Mathematics, Science E Technology Education, 14(3), 1075-1096. https:/ / doi.org/10.12973/ejmste/81553

\section{http://www.ejmste.com}

